University of Nebraska - Lincoln

DigitalCommons@University of Nebraska - Lincoln

2008

Hydrographic Surveys for Six Water Bodies in Eastern Nebraska, 2005-07

Michaela R. Johnson

Michael J. Andersen

Sonja K. Sebree

Follow this and additional works at: https://digitalcommons.unl.edu/usgspubs

Part of the Earth Sciences Commons

Johnson, Michaela R.; Andersen, Michael J.; and Sebree, Sonja K., "Hydrographic Surveys for Six Water Bodies in Eastern Nebraska, 2005-07" (2008). Publications of the US Geological Survey. 9.

https://digitalcommons.unl.edu/usgspubs/9

This Article is brought to you for free and open access by the US Geological Survey at DigitalCommons@University of Nebraska - Lincoln. It has been accepted for inclusion in Publications of the US Geological Survey by an authorized administrator of DigitalCommons@University of Nebraska - Lincoln. 
Prepared in cooperation with the

Nebraska Department of Environmental Quality

\section{Hydrographic Surveys for Six Water Bodies in Eastern Nebraska, 2005-07}

Scientific Investigations Report 2008-5048 



\section{Hydrographic Surveys for Six Water Bodies in Eastern Nebraska, 2005-07}

By Michaela R. Johnson, Michael J. Andersen, and Sonja K. Sebree

Prepared in cooperation with the Nebraska Department of Environmental Quality

Scientific Investigations Report 2008-5048 


\section{U.S. Department of the Interior DIRK KEMPTHORNE, Secretary}

\section{U.S. Geological Survey \\ Mark D. Myers, Director}

\section{U.S. Geological Survey, Reston, Virginia: 2008}

For product and ordering information:

World Wide Web: http://www.usgs.gov/pubprod

Telephone: 1-888-ASK-USGS

For more information on the USGS--the Federal source for science about the Earth, its natural and living resources, natural hazards, and the environment:

World Wide Web: http://www.usgs.gov

Telephone: 1-888-ASK-USGS

Any use of trade, product, or firm names is for descriptive purposes only and does not imply endorsement by the U.S. Government.

Although this report is in the public domain, permission must be secured from the individual copyright owners to reproduce any copyrighted materials contained within this report.

Suggested citation:

Johnson, M.R., Andersen, M.J., and Sebree, S.K., 2008, Hydrographic surveys for six water bodies in eastern Nebraska, 2005-07: U.S. Geological Survey, Scientific Investigations Report 2008-5048, 20 p. 


\section{Contents}

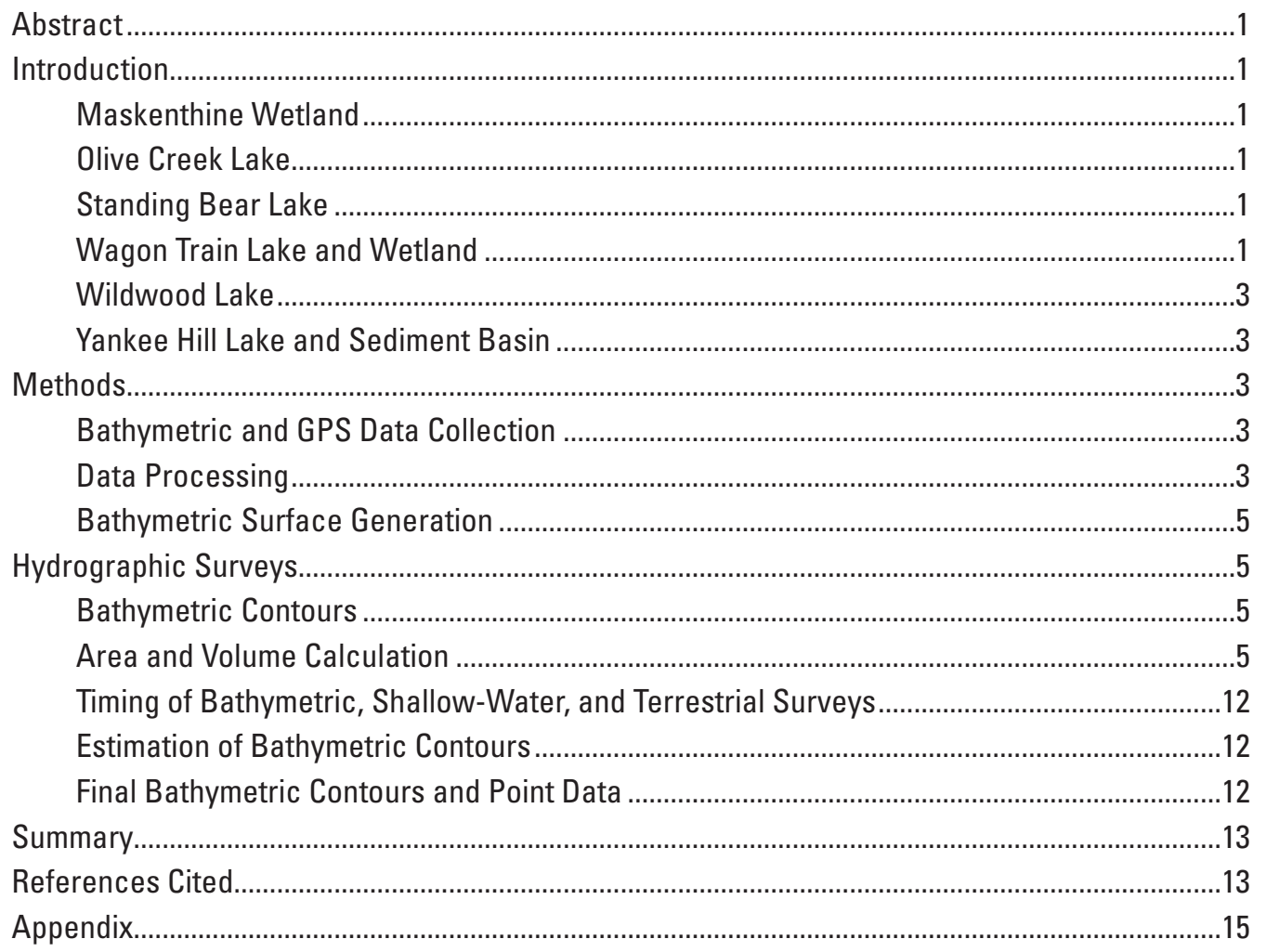

\section{Plates}

1. Bathymetric contours of Maskenthine Wetland near Stanton, Nebraska, 2006 ...............6

2. Bathymetric contours of Olive Creek Lake near Kramer, Nebraska, 2005-06 ...................7

3. Bathymetric contours of Standing Bear Lake in Omaha, Nebraska, 2005-06..................8

4. Bathymetric contours of Wagon Train Lake and Wetland near Hickman, Nebraska,

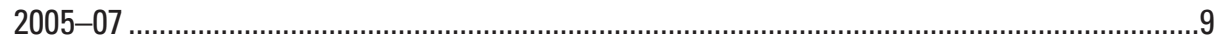

5. Bathymetric contours of Wildwood Lake near Agnew, Nebraska, 2005-06 ...................10

6. Bathymetric contours of Yankee Hill Lake and sediment basin near Denton, Nebraska, 2005-06

\section{Figures}

1. Locations of hydrographic surveys in eastern Nebraska 2005-07...................................2

2. Data collection method for each water body ................................................................. 


\section{Tables}

1. Date of collection for each water body by bathymetric, shallow-water, and terrestrial survey type.

2. Summary statistics for each water body listing conservation-pool (CP) elevation, water-surface elevation when surveyed, surface area and volume at the CP elevation, and minimum and maximum elevations

3. Surface area and storage capacity for Maskenthine Wetland (surface area 7.6 acres and storage capacity 13.9 acre-feet at conservation-pool elevation of 1,545.6 feet) .....16

4. Surface area and storage capacity for Olive Creek Lake (surface area 120.2 acres and storage capacity 1,060.0 acre-feet at conservation-pool elevation of 1,335.32 feet).....17

5. Surface area and storage capacity for Standing Bear Lake (surface area 116.3 acres and storage capacity 1,278.0 acre-feet at conservation-pool elevation of 1,104.41 feet)

6. Surface area and storage capacity for Wagon Train Lake (surface area 260.8 acres and storage capacity 1,942.4 acre-feet at full conservation pool elevation of 1,288.14 feet)

7. Surface area and storage capacity for Wagon Train Wetland (surface area 32.0 acres and storage capacity 70.4 acre-feet at conservation pool elevation of 1,288.14 feet)....19

8. Surface area and storage capacity for Wildwood Lake (surface area 111.0 acres and storage capacity 1,347.1 acre-feet at conservation pool elevation of 1,314.04 feet) ......20

9. Surface area and storage capacity for Yankee Hill Lake (surface area 188.4 acres and storage capacity 1,668.8 acre-feet at conservation pool elevation of 1,245.24 feet) ......21

10. Surface area and storage capacity for Yankee Hill sediment basin (surface area 3.5 acres and storage capacity 11.3 acre-feet at conservation pool elevation of 1,245.24 feet) 


\section{Conversion Factors and Datums}

\begin{tabular}{lcl}
\hline \multicolumn{1}{c}{ Multiply } & By & \multicolumn{1}{c}{ To obtain } \\
\hline inch (in.) & Length & \\
foot (ft) & 2.54 & centimeter $(\mathrm{cm})$ \\
\hline & 0.3048 & meter $(\mathrm{m})$ \\
\hline acre & Area & \\
\hline & 4,047 & square meter $\left(\mathrm{m}^{2}\right)$ \\
\hline acre-foot (acre-ft) & Volume & \\
\hline
\end{tabular}

Vertical coordinate information is referenced to the North American Vertical Datum of 1988 (NAVD 88).

Horizontal coordinate information is referenced to the North American Datum of 1983 (NAD 83). 



\title{
Hydrographic Surveys for Six Water Bodies in Eastern Nebraska, 2005-07
}

\author{
By Michaela R. Johnson, Michael J. Andersen, and Sonja K. Sebree
}

\section{Abstract}

The U.S. Geological Survey, in cooperation with the Nebraska Department of Environmental Quality, completed hydrographic surveys for six water bodies in eastern Nebraska: Maskenthine Wetland, Olive Creek Lake, Standing Bear Lake, Wagon Train Lake and Wetland, Wildwood Lake, and Yankee Hill Lake and sediment basin. The bathymetric data were collected using a boat-mounted survey-grade fathometer that operated at $200 \mathrm{kHz}$, and a differentially corrected Global Positioning System with antenna mounted directly above the echo-sounder transducer. Shallow-water and terrestrial areas were surveyed using a Real-Time Kinematic Global Positioning System. The bathymetric, shallow-water, and terrestrial data were processed in a geographic information system to generate a triangulated irregular network representation of the bottom of the water body. Bathymetric contours were interpolated from the triangulated irregular network data using a 2-foot contour interval. Bathymetric contours at the conservation pool elevation for Maskenthine Wetland, Yankee Hill Lake, and Yankee Hill sediment pond also were interpolated in addition to the 2-foot contours. The surface area and storage capacity of each lake or wetland were calculated for 1-foot intervals of water surface elevation and are tabulated in the Appendix for all water bodies.

\section{Introduction}

Lakes experience physical changes with time as a result of sediment deposition and bank erosion. Understanding the hydrologic and bathymetric characteristics of Nebraska's lakes, and how those characteristics have changed with time, is essential for the effective management of these valuable resources. The U.S. Geological Survey (USGS), in cooperation with Nebraska Department of Environmental Quality, conducted hydrographic surveys to determine the storage capacity of six water bodies in eastern Nebraska (fig. 1). The purpose of this report is to document the methods used and present the results of the hydrographic surveys conducted 2005 through 2007.

\section{Maskenthine Wetland}

The Maskenthine Wetland is located near Stanton, Nebraska (fig. 1). A small dam was constructed in 1989 to create the 7.6-acre wetland that also serves as a sediment basin (Lower Elkhorn Natural Resources District, 2008). The wetland filters out sediment from surface water flowing into Maskenthine Lake. Maskenthine Wetland was dry at the time of the survey.

\section{Olive Creek Lake}

The Olive Creek Lake near Kramer, Nebraska, was formed when a dam was built on the south tributary of Olive Branch in 1964 (fig. 1). The 174-acre lake was primarily used for flood control and recreation (U.S. Army Corps of Engineers, 2006a). It was modified in 2002-03 to renovate the fishery by constructing jetty and island habitat structures. Two small dams also were constructed to form sediment basins on two tributaries at the upper end of the lake (G. Michl, Nebraska Department of Environmental Quality, written commun., 2007). The scope of the hydrographic survey for this lake was limited to the area downstream from these dams.

\section{Standing Bear Lake}

The Standing Bear Lake was formed when a dam was built on a tributary of Papillion Creek in Omaha, Nebraska, in 1977 (fig. 1). The 137-acre lake as built was constructed to provide flood control and recreation (U.S. Army Corps of Engineers, 2006b). The lake was surveyed in 1998 by the Nebraska Department of Environmental Quality with a surface area of 104 acres (Nebraska Department of Environmental Quality, 2003).

\section{Wagon Train Lake and Wetland}

The Wagon Train Lake near Hickman, Nebraska, was formed when a dam was built on the north tributary of Hickman Branch in 1963 (fig. 1). The 260-acre lake was constructed to provide flood control and recreation. The 30 -acre 


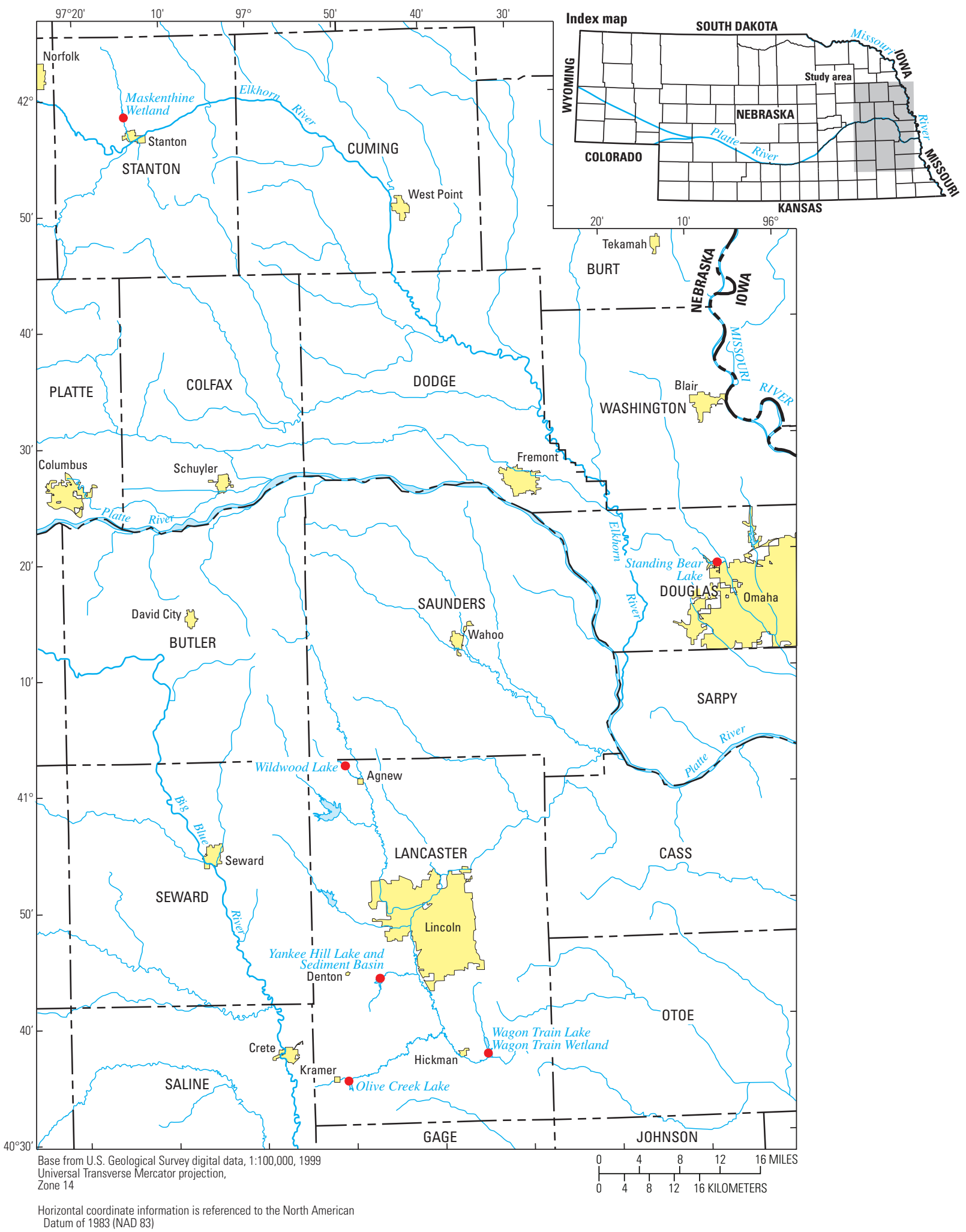

EXPLANATION

Yankee Hill Lake and
Sediment Basin Bathymetry study site and water body name

Figure 1. Locations of hydrographic surveys in eastern Nebraska 2005-07. 
wetland was created in 2002 when the lake was renovated to provide shoreline stabilization and reduce sediment inflow to the lake by creating a sediment basin and wetland areas (Nebraska Department of Environmental Quality, 2002a).

\section{Wildwood Lake}

The Wildwood Lake near Agnew, Nebraska, was formed when a dam was constructed on a tributary to North Oak Creek in 1980 (fig. 1). The 110-acre flood-control and recreational lake was renovated to reduce sediment inflow to the reservoir and add habitat structures in 2001. During the renovation parts of the lake were deepened, islands were created and shoreline scallops were created to create a varying depth shoreline (Lower Platte South Natural Resources District, 2008).

\section{Yankee Hill Lake and Sediment Basin}

The Yankee Hill Lake near Denton, Nebraska, was formed when a dam was constructed on Cardwell Branch in 1965 (fig. 1). The 211-acre flood-control and recreational lake was renovated in 2004 (Nebraska Department of Environmental Quality, 2002b). Habitat structures were added to the lake and sediment basins were constructed on the two major tributaries to the lake (Nebraska Department of Environmental Quality, 2007). Yankee Hill Lake was dry at the time of the survey. The scope of the hydrographic survey for this lake was limited to the sediment basin on the west tributary and the lake downstream from these sediment basins.

\section{Methods}

Mapping the entire conservation pool of each water body was completed by hydrographic surveys, a combination of bathymetric, shallow-water, and terrestrial surveying. Bathymetry was surveyed using a differential Global Positioning System (DGPS) receiver together with a digital survey fathometer. Water-surface elevations were recorded during bathymetric surveying to allow later calculation of bottom elevations by subtracting water depth. Water-surface elevations were determined from the vertical distance measured from a fixed reference mark location down to the water surface.

The shallow-water and terrestrial surveys were conducted where additional data were needed, that is, in shallow water where water depths were less than 3 feet and for terrestrial areas up to the conservation pool elevation. These data were collected using Real-Time Kinematic (RTK) Global Positioning System (GPS).

The bathymetric, shallow-water, and terrestrial data were combined using geographic information systems (GIS) to map the bathymetry of the conservation pool, and to determine the surface area and storage capacity (volume) of each water body.
Contour lines of equal elevation were plotted, reviewed, and edited for accuracy and consistency. Bathymetric maps were constructed to present these contours.

\section{Bathymetric and GPS Data Collection}

All bathymetric data were collected on a series of crosssection lines oriented perpendicularly to the longitudinal axis of the lake. These cross-sections were spaced 10 to 15 feet apart. The bathymetric surveys were conducted by boat from June 8, 2005, through June 24, 2005 (table 1). These surveys were conducted independently from the shallow-water and terrestrial surveys that were necessary to characterize impoundment structures, the areas of the lake too shallow to survey by boat, or areas that were dry at the time of surveying. Shallowwater and terrestrial surveys occurred primarily from June 28, 2005, through November 8, 2006. Additional terrestrial surveying occurred on July 15, 2007. Maskenthine Wetland and Yankee Hill Lake and sediment basin were surveyed solely with terrestrial methods because they were dry at the time they were surveyed (fig. 2). The remaining water bodies were surveyed using a combination of bathymetric, shallow-water, and terrestrial methods (fig. 2).

The bathymetric data were collected using a surveygrade fathometer operating at $200 \mathrm{kHz}$ (Innerspace Technology, 2001) and DGPS mounted on a boat. The fathometer was used to collect water-depth data at discrete points approximately 0.1 foot apart depending on water depth, boat speed, and other operational parameters. The nominal accuracy of the bathymetric data was plus or minus 0.5 foot.

Data for shallow-water and terrestrial areas were collected with RTK GPS receivers. At each lake, the GPS base station was positioned at a benchmark having an established location, and the collected data were processed through the National Geodetic Survey Online Positioning User Service (OPUS). The accuracy of these benchmark locations were reported to be within 2 inches horizontally and vertically. The base station transmitted radio signals to roving GPS units to maintain the vertical and horizontal control during data collection. The scope of the terrestrial surveys included areas between the shallow-water bottom elevations (areas with less than 3-foot water depth at the time of bathymetric surveying) and the conservation pool elevation, islands, impoundment structures, jetties, and the fixed reference mark locations used during the bathymetric surveys.

\section{Data Processing}

The data from the bathymetric, shallow-water, and terrestrial surveys were formatted as text files of northing and easting coordinates in meters and elevation in feet. All data were converted to a common map projection [Universal Transverse Mercator, zone 14, horizontal North American Datum of 1983 and North American Vertical Datum of 1988 for use in GIS processing (Snyder, 1987)]. The text file from 


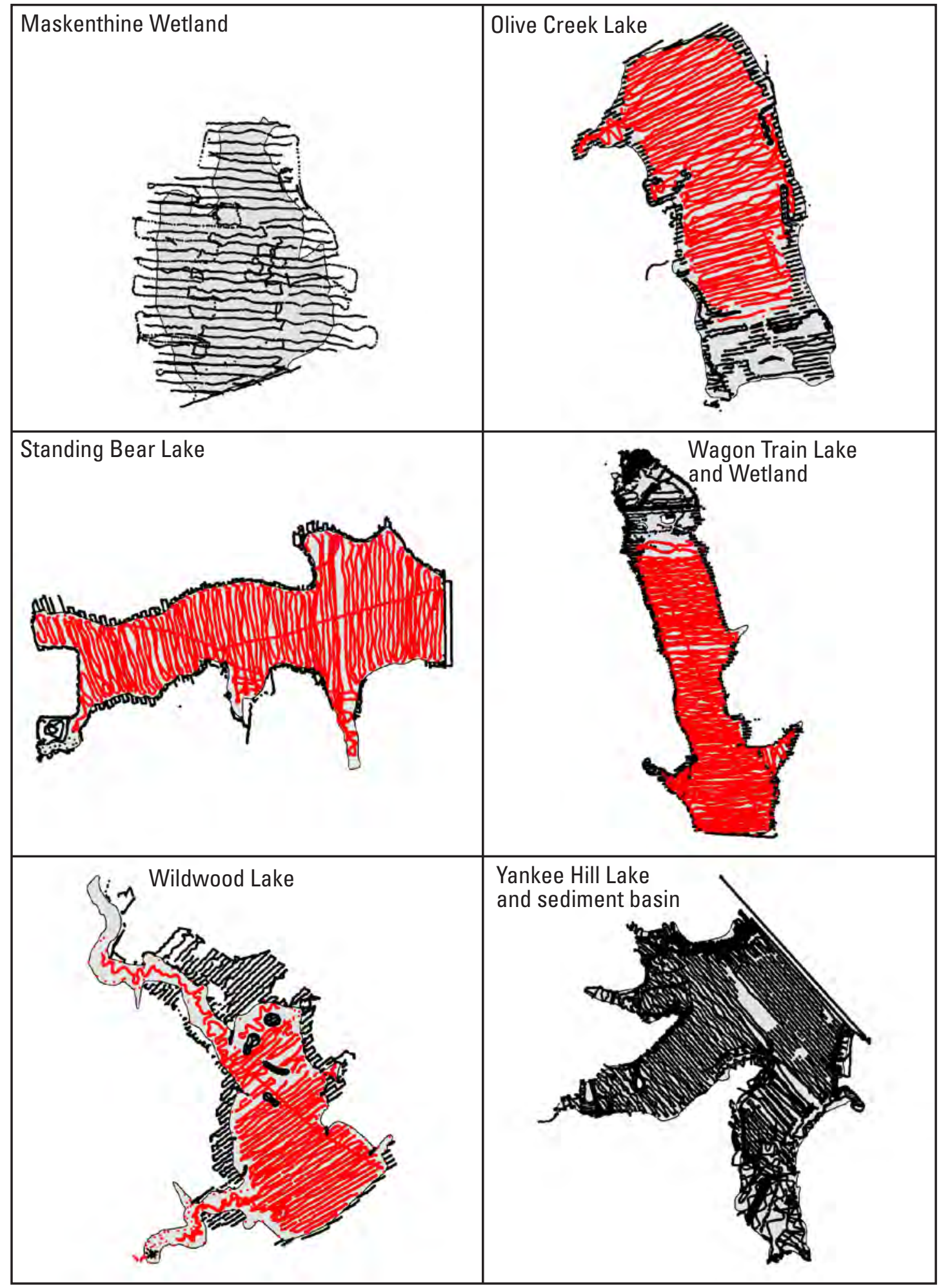

EXPLANATION

._. Bathymetry point-Elevation point collected by boat-mounted fathometer for bathymetric surveys

- -. RTK GPS point-Elevation point collected by a surveying person using a Real Time Kinematic (RTK) Global Navigation Satellite System (GPS) for shallow-water or terrestrial surveys

Figure 2. Data collection method for each water body. 
Table 1. Dates of surveys for each water body by bathymetric, shallow-water, and terrestrial survey type.

[DGPS, differential Global Positioning System; RTK GPS, Real-Time Kinematic Global Positioning System; --, bathymetric data not required because lake was dry]

\begin{tabular}{lcl}
\hline \multicolumn{1}{c}{ Water body } & $\begin{array}{c}\text { Bathymetric survey } \\
\text { dates (DGPS) }\end{array}$ & \multicolumn{1}{c}{$\begin{array}{c}\text { Shallow-water and terrestrial survey dates } \\
\text { (RTK GPS) }\end{array}$} \\
\hline Maskenthine Wetland & -- & May 10, 2006 and July 11-12, 2006 \\
Olive Creek Lake & June 8-9, 2005 & July 14, 2006 and July 18-20, 2006 \\
Standing Bear Lake & June 10-11, 2005 & October 24-25, 2006 \\
Wagon Train Lake and Wetland & June 12, 2005 & July 15, 2005, July 19, 2005, August 1, 2006, and July 15, 2007 \\
& June 14, 2005 & \\
June 20-22, 2005 & Oune 22-24, 2005 & October 31, 2006, November 1, 2006, and November 8, 2006 \\
Wildwood Lake & -- & June 28-30, July 12, 2005, and July 5-6, 2006
\end{tabular}

each lake or wetland was used to generate point features as a shapefile (Environmental Systems Research Institute, 1998). Each point shapefile was plotted and compared to a digital orthophotographic quarter quadrangle (DOQQ) of the area surrounding the water body using ArcMap to ensure accurate georeferencing and to inspect for data errors (U.S. Geological Survey, 1998). All GIS processing used the Environmental Systems Research Institute, Inc. (ESRI), Redlands, Calif., GIS software, ArcGIS, an integrated collection of GIS software products including ArcMap, ArcEdit, and the 3-D Analyst extension.

\section{Bathymetric Surface Generation}

A triangulated irregular network (TIN) surface was used to represent the bottom of the water body. The initial TIN surface was generated from the combined bathymetric, shallowwater, and terrestrial point data. Based on the TIN surface, contours were interpolated using a 2-foot contour interval. Bathymetric contours at the conservation pool elevation for Maskenthine Wetland, Yankee Hill Lake, and Yankee Hill sediment pond also were interpolated in addition to the 2-foot contours. The contour lines were plotted over the DOQQ and a Digital Raster Graphic (DRG) topographic map to assess any errors or anomalies in either the TIN or point data. After several iterations, the final contour lines interpolated from the TIN surface were smoothed within ArcEdit using spline functions and grain tolerance settings. Additional editing and smoothing of the final contour lines was done within ArcMap to ensure consistency with land features in the DOQQ and the surveyed data.

The final TIN was generated from the combined bathymetric, shallow-water, and terrestrial point data; final contours; and a polygon defining the water body. The contour line at the conservation pool elevation or, if greater, the maximum elevation contour line, was converted to a single polygon defining the extent of the water body. The extent polygon was the boundary used to confine the final TIN to the area of each water body. The final TIN was used to produce surface area and storage capacity (volume) tables detailing the size in acres and storage capacity in acre-feet for each 1-foot unit change in water-surface elevation.

\section{Hydrographic Surveys}

The results of the bathymetric surveys are presented in this section. The bathymetric contours are first presented as a series of six maps. Summary statistics for the surface area and storage capacity (volumes) calculated for each water body are tabulated in a second section, and the individual 1-foot interval surface-area and storage-capacity tables are presented in the appendix of this report. Additionally, the Final Bathymetric Contours and Point Data section describes where contour shapefiles and shapefiles of surveyed points are available electronically for download from a Web link listed in the section.

\section{Bathymetric Contours}

The combined bathymetric, shallow-water, and terrestrial data were used to generate a TIN surface representing the bottom of each water body. Bathymetric contours interpolated from the TIN surface were smoothed and matched against the land features in the DOQQ and the bathymetric data. A map showing the final bathymetric contours for each lake or wetland was produced (plates 1-6).

\section{Area and Volume Calculation}

Each water body's surface area and storage capacity table was calculated from the final TIN and is listed in tables 


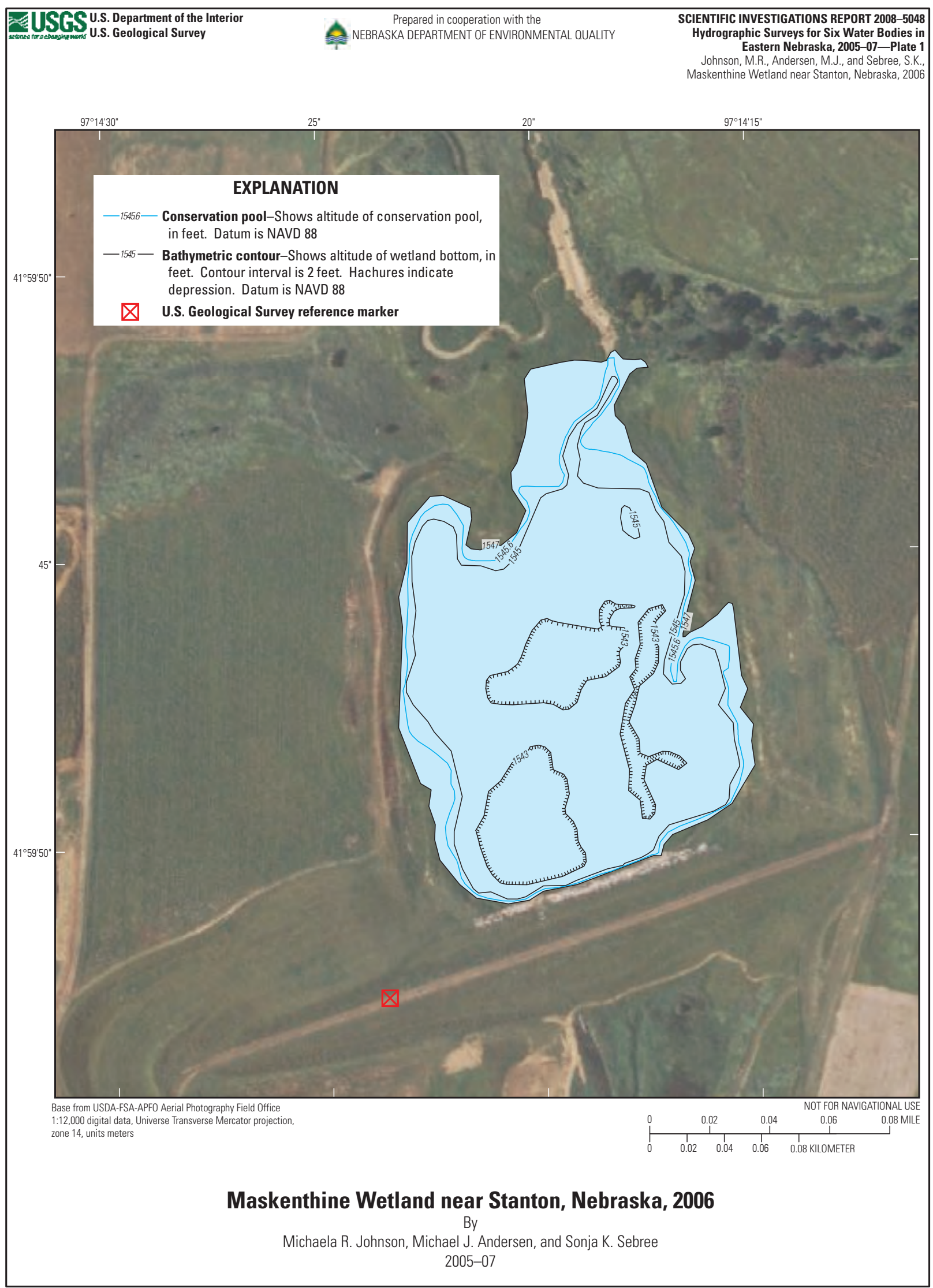

Plate 1. Bathymetric contours of Maskenthine Wetland near Stanton, Nebraska, 2006. 


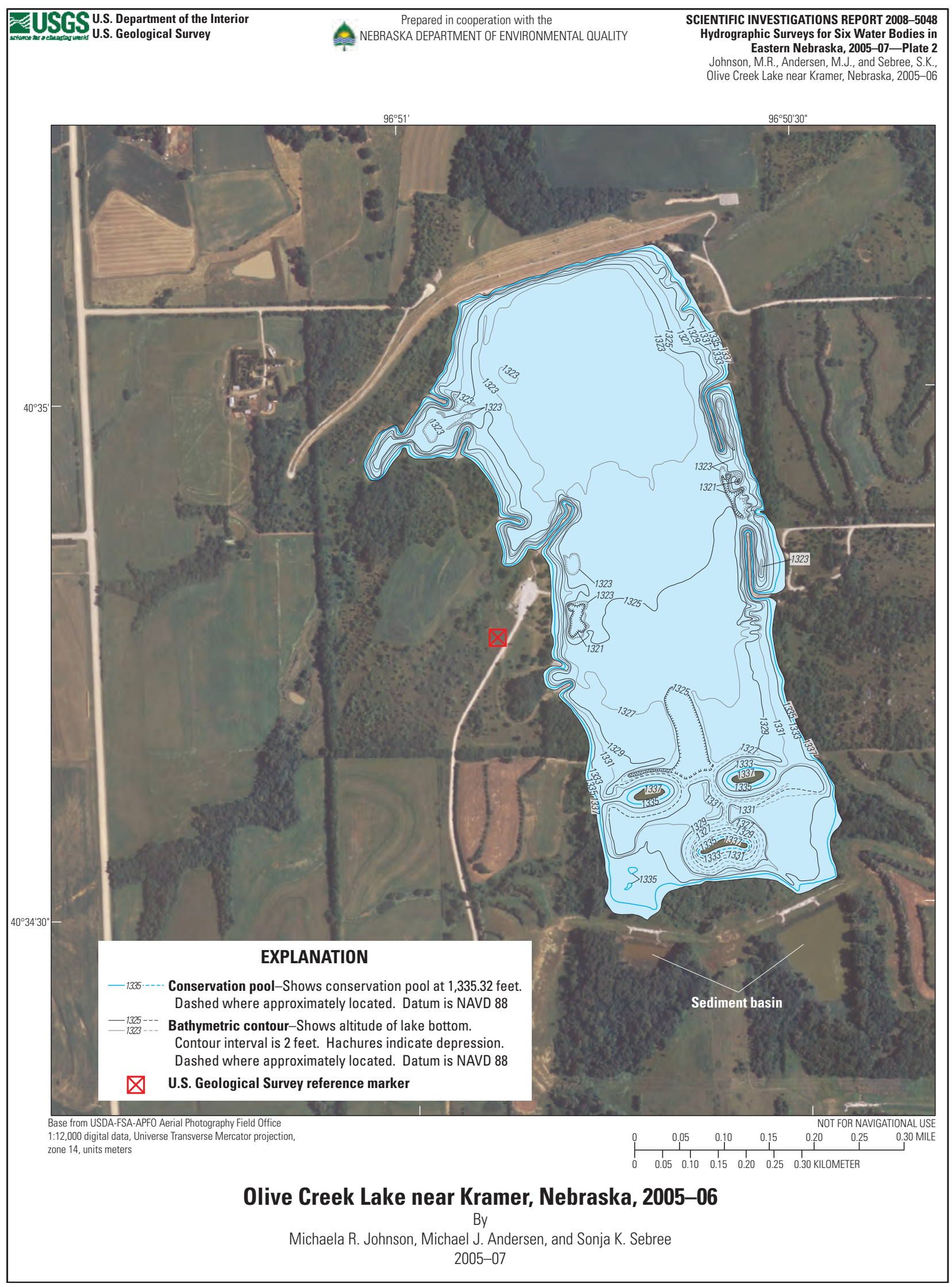

Plate 2. Bathymetric contours of Olive Creek near Kramer, Nebraska, 2005-06. 


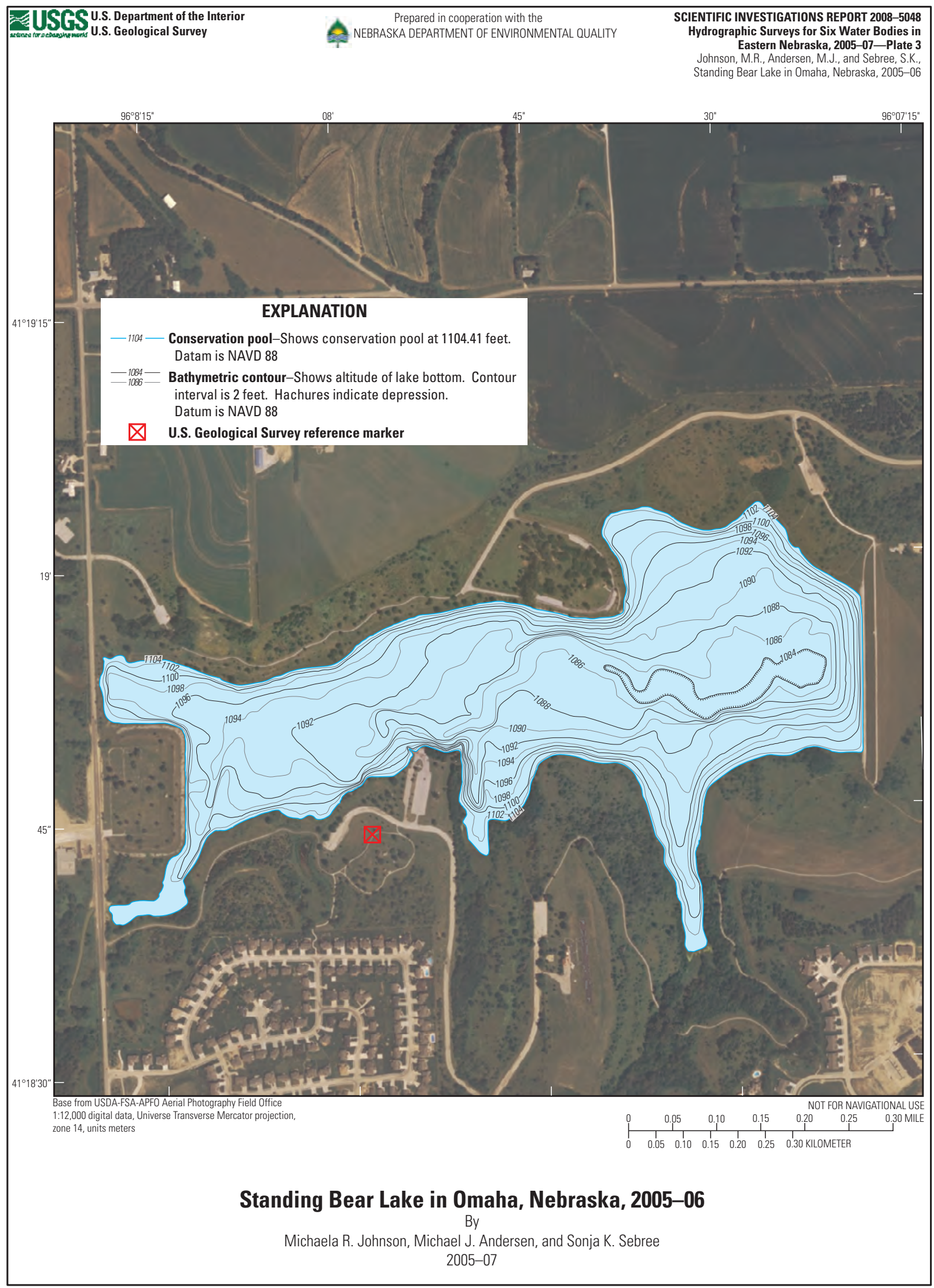

Plate 3. Bathymetric contours of Standing Bear Lake in Omaha, Nebraska, 2005-06. 


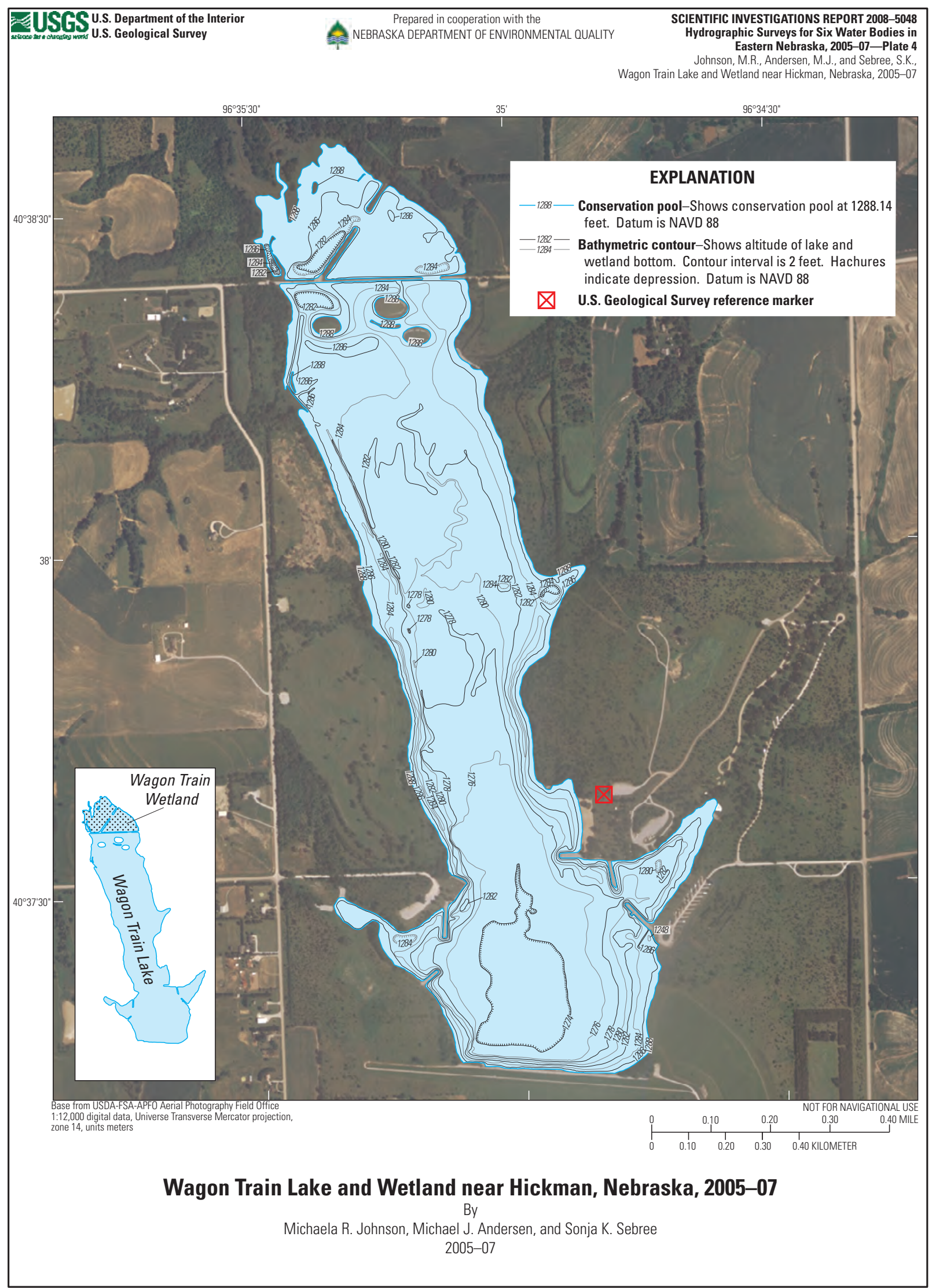

Plate 4. Bathymetric contours of Wagon Train Lake and Wetland near Hickman, Nebraska, 2005-07. 


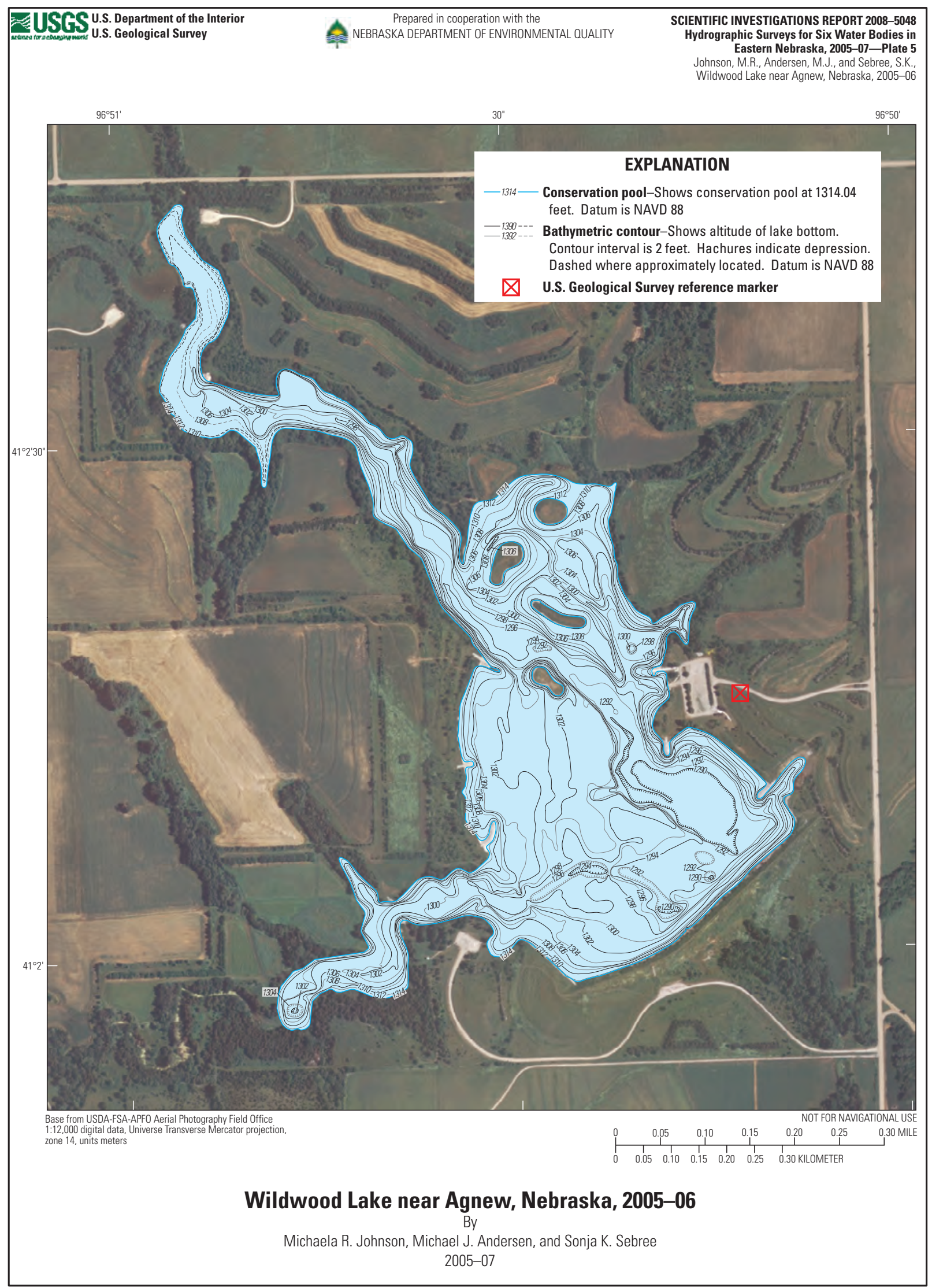

Plate 5. Bathymetric contours of Wildwood Lake near Agnew, Nebraska, 2005-06. 


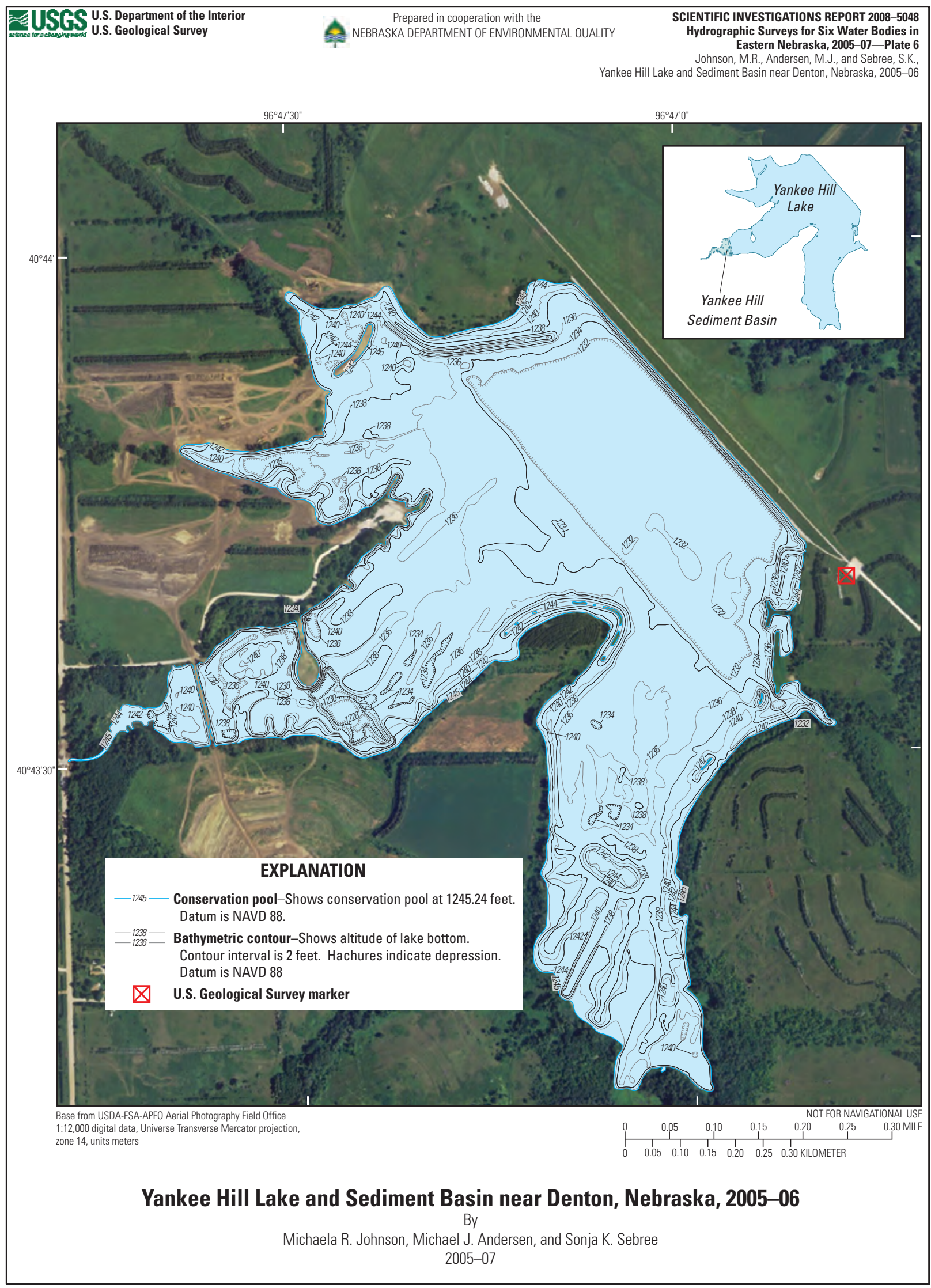

Plate 6. Bathymetric contours of Yankee Hill Lake and sediment basin near Denton, Nebraska, 2005-06. 
3 through 10 in the appendix, at the back of this report. The surface area and storage capacity tables were calculated for each 1-foot change in elevation within the 3-D Analyst extension in ArcMap and written to a user-assigned output text file. Statistics for each water body obtained from the surface area and volume tables are listed in table 2. Separate area and capacity tables were generated for Wagon Train Lake, Wagon Train Wetland, Yankee Hill Lake, and Yankee Hill sediment basin.

\section{Timing of Bathymetric, Shallow-Water, and Terrestrial Surveys}

Bathymetric, shallow-water, and terrestrial surveys were conducted 1 year apart. The shallow-water and terrestrial surveys began at the elevation where it became too shallow (less than 3 feet deep) for the bathymetric survey method. The impoundment structures and jetties were static between years, being composed of concrete rip-rap. Shallow water features and other terrestrial features may have undergone erosion or siltation in the interim between these surveys. These processes could have had some impact on the surface area and storage capacity; however, the difference in elevations of points replicated between years of survey did not exceed 0.5 foot, which also is the accuracy range associated with the bathymetric survey methods. Shallow-water and terrestrial data points collected in 2007 at Wagon Train Wetland also were within 0.5 foot of the data collected at replicate locations in 2006.

\section{Estimation of Bathymetric Contours}

Bathymetric contours were estimated for some areas where bathymetric, shallow-water, and terrestrial data were not collected. Existing ancillary data were used to help locate these contours. DOQQ imagery aided in reshaping contours to follow the features of the water body, such as islands and jetties. Bathymetric contours were estimated using this method near the three islands in the southern part of Olive Creek Lake. The channels connecting the open lake with shoals and pools behind these islands were not accessible by boat and RTK GPS data were not collected. The northern arm of Wildwood Lake also contains bathymetric contours that were estimated using a combination of RTK GPS data, DOQQ, and topographic maps (DRG).

\section{Final Bathymetric Contours and Point Data}

The final contours and the combined bathymetric, shallow-water, and terrestrial point data for each water body are available for electronic download from this Web link.

Data available on the Web are compressed in .zip format. WinZip® is a Windows-based file compression utility. A program similar to this is needed to extract the data files. A downloadable trial copy of WinZip software is available on the Web at: http://www.winzip.com/downwz.htm (accessed February 21, 2008).

The compressed data files, one per water body, contain geospatial data sets in shapefile format (Environmental Systems Research Institute, Inc., 1998). A shapefile consists of a main coordinates file, an index file, and a dBASE® format attribute table. Each record in the main file describes a spatial object with a list of its vertices and their coordinates. In the index file, each record contains the offset of the corresponding main file record from the beginning of the main file. The dBASE table contains feature-attribute records, one per feature, that tabulate additional information describing the features.

The 12 shapefiles that compose the downloadable sets of geospatial data are listed and described as follows:

Table 2. Summary statistics for each water body listing conservation-pool (CP) elevation, water-surface elevation when surveyed, surface area and volume at the CP elevation, and minimum and maximum contour elevations.

[All elevations are referenced to the North American Vertical Datum of 1988 (NAVD 88); --, water body was dry at the time of survey]

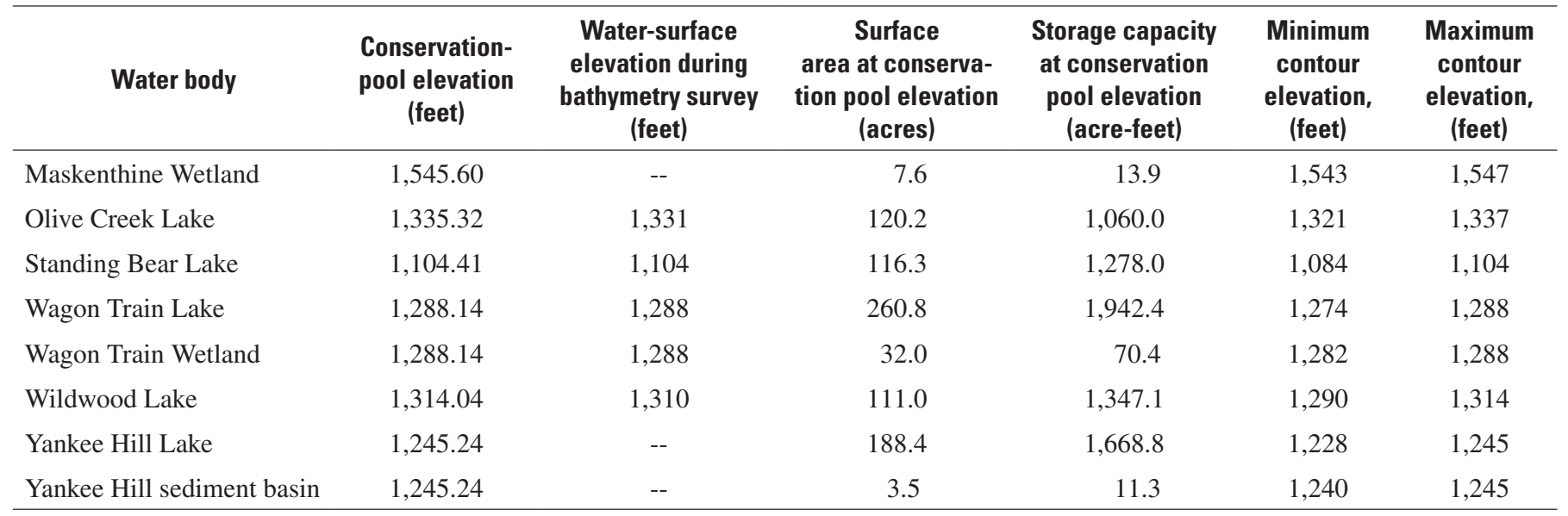


1. SIR08_5048_mkwcontour-bathymetric contours for Maskenthine Wetland (arc);

2. SIR08_5048_mkwpoints_-bathymetric point data for Maskenthine Wetland (point);

3. SIR08_5048_olvcontour_bathymetric contours for Olive Creek Lake (arc);

4. SIR08_5048_olvpoints_bathymetric point data for Olive Creek Lake (point);

5. SIR08_5048_stbcontour-bathymetric contours for Standing Bear Lake (arc);

6. SIR08_5048_stbpoints—bathymetric point data for Standing Bear Lake (point);

7. SIR08_5048_wtcontour_bathymetric contours for Wagon Train Lake and Wetland (arc);

8. SIR08_5048_wtpoints_bathymetric point data for Wagon Train Lake and Wetland (point);

9. SIR08_5048_wwrcontour_bathymetric contours for Wildwood Lake (arc);

10. SIR08_5048_wwrpoints—bathymetric point data for Wildwood Lake (point);

11. SIR08_5048_ynkcontour-bathymetric contours for Yankee Hill Lake and sediment basin (arc); and

12. SIR08_5048_ynkpoints_-bathymetric point data for Yankee Hill Lake and sediment basin (point).

A compressed file containing metadata documentation is also available from the Web link.

\section{Summary}

Hydrographic surveys were completed for six water bodies in eastern Nebraska: Maskenthine Wetland, Olive Creek Lake, Standing Bear Lake, Wagon Train Lake and Wetland, Wildwood Lake, and Yankee Hill Lake and sediment basin. Bathymetric, shallow-water, and terrestrial data were collected on a series of cross-sections spaced 10 to 15 feet apart across each water body and aligned perpendicularly to the longitudinal axis of the water body. The bathymetric data were collected using a boat-mounted survey-grade fathometer that operated at $200 \mathrm{kHz}$ and a Differential Global Positioning System (DGPS) receiver. Data for shallow-water and terrestrial areas were collected using Real-Time Kinematic (RTK) global positioning system units. The bathymetric, shallow-water, and terrestrial data were combined and formatted as text files of northing and easting coordinates and elevations. For each water body, a triangulated irregular network (TIN) surface was generated from the bathymetric data to represent the bottom of the lake or wetland. Contours of the triangulated irregular network surface were interpolated using a 2-foot contour interval and subsequently were smoothed to create the final map. Bathymetric contours at the conservation pool elevation for Maskenthine Wetland, Yankee Hill Lake, and Yankee Hill sediment pond also were interpolated in addition to the 2-foot contours. The surface area and storage-capacity were calculated for 1-foot intervals of water-surface elevation. Tables of the surface area and storage capacity for each water body are included in the appendix.

\section{References Cited}

Environmental Systems Research Institute, 1998, ESRI Shapefile technical description: Redlands, Calif., Environmental Systems Research Institute, 28 p., accessed February 21, 2008, at http://www.esri.com/library/whitepapers/pdfs/ shapefile.pdf.

Innerspace Technology, 2001, Model 456 survey depth sounder operating manual: Waldwick, N.J., Innerspace Technology, 56 p.

Lower Elkhorn Natural Resources District, 2008, Maskenthine Lake Recreation Area: Norfolk, Nebr., Lower Elkhorn Natural Resources District, 2 p., accessed April 8, 2008, at http://www.lenrd.org/pdfs/maskenthine_map.pdf.

Lower Platte South Natural Resources District, 2008, Wildwood Lake: Lincoln, Nebr., Lower Platte South Natural Resources District, accessed April 11, 2008, at http://www. lpsnrd.org/docs/MajorProjects/wildwoodrenov.htm.

Nebraska Department of Environmental Quality, 2002a, Total maximum daily loads for Wagon Train Lake-Lancaster County, Nebraska: Lincoln, Nebr., Nebraska Department of Environmental Quality Planning Unit, Water Quality Division, 19 p., accessed April 11, 2008, at http://www.epa.gov/ region7/water/pdf/wagon_train_lake_final_tmdl_1002.pdf.

Nebraska Department of Environmental Quality, 2002b, Total maximum daily loads for Yankee Hill Lake-Lancaster County, Nebraska: Lincoln, Nebr., Nebraska Department of Environmental Quality Planning Unit, Water Quality Division, 20 p., accessed April 17, 2008, at http://www.epa.gov/ region7/water/pdf/yankee_hill_lake_final_tmdl_0802.pdf.

Nebraska Department of Environmental Quality, 2003, Total maximum daily loads for Standing Bear Lake-Douglas County, Nebraska: Lincoln, Nebr., Nebraska Department of Environmental Quality Planning Unit, Water Quality Division, 18 p., accessed April 11, 2008, at http://www.epa.gov/ region7/water/pdf/standing_bear_lake_final_tmdl.pdf.

Nebraska Department of Environmental Quality, 2007, Quick guide to Nebraska nonpoint source projects: Lincoln, Nebr., Nebraska Department of Environmental Quality, Nonpoint Souce Pollution Management Program, 3 p., accessed April 17, 2008, at http://www.deq.state.ne.us/SurfaceW.nsf/23e5e3 9594c064ee852564ae004fa010/975aab17bda3649a862573 cb00708dd3/\$FILE/ATTJY8BD/FY2003.pdf.

Snyder, J.P., 1987, Map projections: A working manual: U.S. Geological Survey Professional Paper 1395, 385 p. 
U.S. Army Corps of Engineers, 2006a, Value to the Nation: Lake level report Olive Creek Lake, accessed April 11, 2008, at http://www.vtn.iwr.usace.army.mil/recreation/ reports/lake.asp? $I D=318$.

U.S. Army Corps of Engineers, 2006b, Value to the Nation: Lake level report Standing Bear Lake, accessed April 11, 2008, at http://www.vtn.iwr.usace.army.mil/recreation/ reports/lake.asp? $I D=389$.

U.S. Geological Survey, 1998, Digital orthophoto quadrangles: U.S. Geological Survey Fact Sheet 129-95, 2 p. 
Appendix 
Table 3. Surface area and storage capacity for Maskenthine Wetland (surface area 7.6 acres and storage capacity 13.9 acre-feet at conservation-pool elevation of 1,545.6 feet).

\begin{tabular}{ccc}
\hline Elevation, in feet & Surface area, in acres & Storage capacity, in acre-feet \\
\hline $1,543.0$ & 1.6 & 0.5 \\
$1,544.0$ & 4.7 & 3.9 \\
$1,545.0$ & 6.7 & 9.6 \\
$1,546.0$ & 8.1 & 17.1 \\
$1,547.0$ & 9.1 & 25.7 \\
\hline
\end{tabular}


Table 4. Surface area and storage capacity for Olive Creek Lake (surface area 120.2 acres and storage capacity 1,060.0 acre-feet at conservation-pool elevation of $1,335.32$ feet).

\begin{tabular}{ccc}
\hline Elevation, in feet & Surface area, in acres & Storage capacity, in acre-feet \\
\hline $1,320.0$ & 0.1 & 0.1 \\
$1,321.0$ & .5 & .4 \\
$1,322.0$ & 1.0 & 1.2 \\
$1,323.0$ & 27.3 & 12.6 \\
$1,324.0$ & 43.1 & 48.4 \\
$1,325.0$ & 54.4 & 97.3 \\
$1,326.0$ & 64.5 & 157.1 \\
$1,327.0$ & 74.2 & 226.4 \\
$1,328.0$ & 84.0 & 306.5 \\
$1,329.0$ & 88.5 & 392.5 \\
$1,330.0$ & 94.7 & 485.2 \\
$1,331.0$ & 99.0 & 582.0 \\
$1,332.0$ & 104.8 & 684.0 \\
$1,333.0$ & 110.7 & 791.8 \\
$1,334.0$ & 115.0 & 904.7 \\
$1,335.0$ & 119.0 & $1,021.7$ \\
$1,336.0$ & 122.2 & $1,142.4$ \\
$1,337.0$ & 125.1 & $1,266.0$ \\
\hline
\end{tabular}


Table 5. Surface area and storage capacity for Standing Bear Lake (surface area 116.3 acres and storage capacity 1,278.0 acre-feet at conservation-pool elevation of 1,104.41 feet).

\begin{tabular}{ccc}
\hline $\begin{array}{c}\text { Elevation, } \\
\text { in feet }\end{array}$ & $\begin{array}{c}\text { Surface area, } \\
\text { in acres }\end{array}$ & $\begin{array}{c}\text { Storage capacity, } \\
\text { in acre-feet }\end{array}$ \\
\hline $1,083.0$ & 1.4 & 0.4 \\
$1,084.0$ & 4.0 & 3.0 \\
$1,085.0$ & 7.3 & 8.7 \\
$1,086.0$ & 12.3 & 18.3 \\
$1,087.0$ & 17.6 & 33.0 \\
$1,088.0$ & 23.0 & 53.4 \\
$1,089.0$ & 28.9 & 79.4 \\
$1,090.0$ & 34.9 & 111.3 \\
$1,091.0$ & 41.2 & 149.3 \\
$1,092.0$ & 49.3 & 194.4 \\
$1,093.0$ & 56.6 & 247.5 \\
$1,094.0$ & 63.9 & 307.7 \\
$1,095.0$ & 70.8 & 375.2 \\
$1,096.0$ & 77.6 & 449.4 \\
$1,097.0$ & 83.5 & 530.1 \\
$1,098.0$ & 88.9 & 616.3 \\
$1,099.0$ & 94.0 & 707.9 \\
$1,100.0$ & 99.0 & 804.2 \\
$1,101.0$ & 103.4 & 905.4 \\
$1,102.0$ & 107.0 & $1,010.7$ \\
$1,103.0$ & 110.0 & $1,119.3$ \\
$1,104.0$ & 114.2 & $1,231.5$ \\
\hline
\end{tabular}


Table 6. Surface area and storage capacity for Wagon Train Lake (surface area 260.8 acres and storage capacity 1,942.4 acre-feet at full conservation pool elevation of 1,288.14 feet).

\begin{tabular}{ccc}
\hline $\begin{array}{c}\text { Elevation, } \\
\text { in feet }\end{array}$ & $\begin{array}{c}\text { Surface area, } \\
\text { in acres }\end{array}$ & $\begin{array}{c}\text { Storage capacity, } \\
\text { in acre-feet }\end{array}$ \\
\hline $1,273.0$ & 1.4 & 0.3 \\
$1,274.0$ & 15.9 & 7.5 \\
$1,275.0$ & 35.6 & 33.6 \\
$1,276.0$ & 52.7 & 78.4 \\
$1,277.0$ & 64.0 & 137.0 \\
$1,278.0$ & 78.2 & 207.9 \\
$1,279.0$ & 92.5 & 293.8 \\
$1,280.0$ & 104.9 & 392.1 \\
$1,281.0$ & 124.3 & 507.0 \\
$1,282.0$ & 147.2 & 642.6 \\
$1,283.0$ & 167.8 & 801.6 \\
$1,284.0$ & 187.2 & 978.1 \\
$1,285.0$ & 216.5 & $1,182.6$ \\
$1,286.0$ & 234.9 & $1,408.6$ \\
$1,287.0$ & 249.0 & $1,651.7$ \\
$1,288.0$ & 259.3 & $1,905.9$ \\
\hline
\end{tabular}

Table 7. Surface area and storage capacity for Wagon Train Wetland (surface area 32.0 acres and storage capacity 70.4 acre-feet at conservation pool elevation of 1,288.14 feet).

\begin{tabular}{ccc}
\hline $\begin{array}{c}\text { Elevation, } \\
\text { in feet }\end{array}$ & $\begin{array}{c}\text { Surface area, } \\
\text { in acres }\end{array}$ & $\begin{array}{c}\text { Storage capacity, } \\
\text { in acre-feet }\end{array}$ \\
\hline $1,282.0$ & 1.2 & 0.4 \\
$1,283.0$ & 1.7 & 1.9 \\
$1,284.0$ & 2.7 & 4.0 \\
$1,285.0$ & 6.2 & 8.4 \\
$1,286.0$ & 14.6 & 18.2 \\
$1,287.0$ & 23.9 & 38.8 \\
$1,288.0$ & 31.1 & 66.0 \\
\hline
\end{tabular}


Table 8. Surface area and storage capacity for Wildwood Lake (surface area 111.0 acres and storage capacity 1,347.1 acre-feet at conservation pool elevation of 1,314.04 feet).

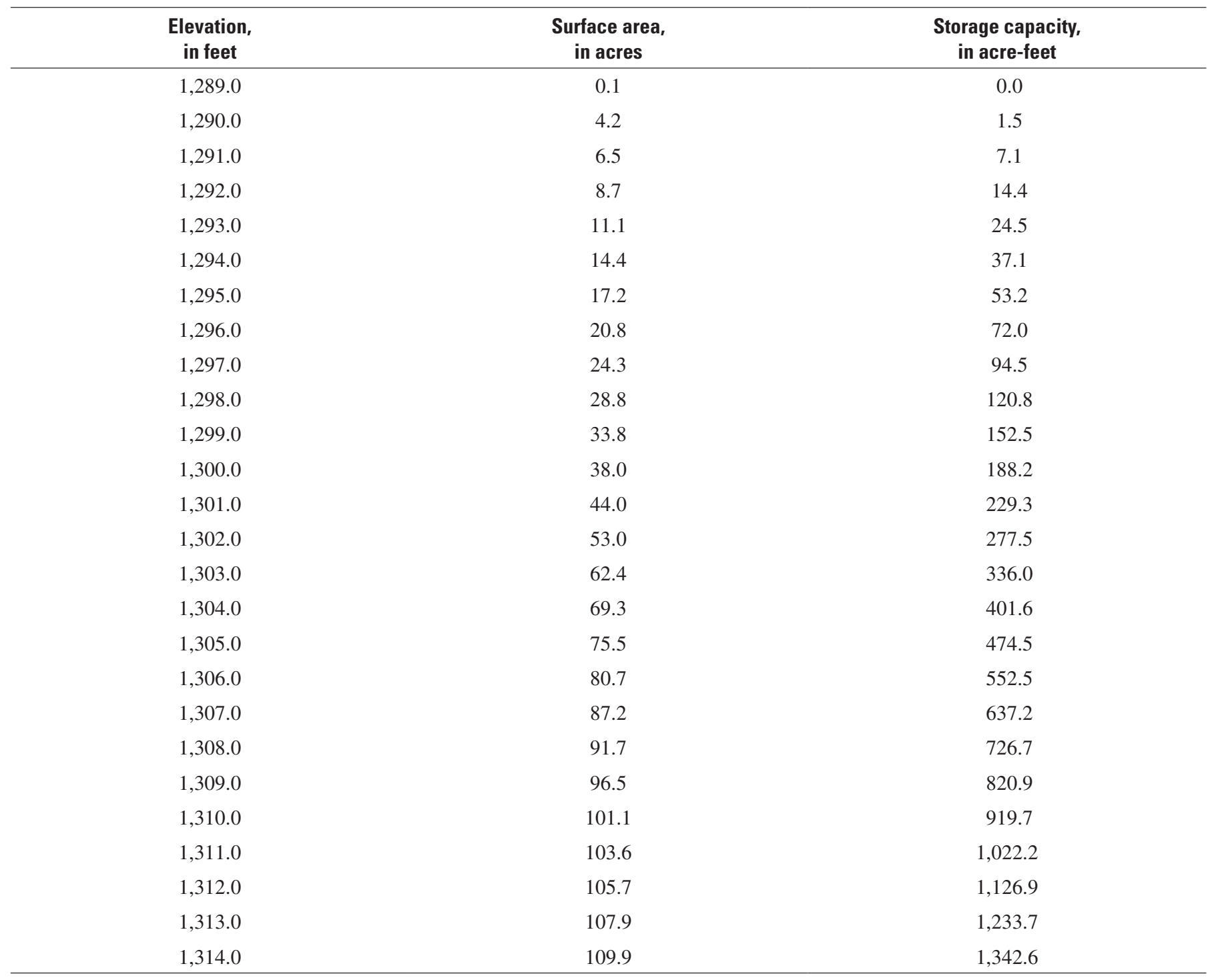


Table 9. Surface area and storage capacity for Yankee Hill Lake (surface area 188.4 acres and storage capacity 1,668.8 acre-feet at conservation pool elevation of 1,245.24 feet).

\begin{tabular}{ccc}
\hline $\begin{array}{c}\text { Elevation, } \\
\text { in feet }\end{array}$ & $\begin{array}{c}\text { Surface area, } \\
\text { in acres }\end{array}$ & $\begin{array}{c}\text { Storage capacity, } \\
\text { in acre-feet }\end{array}$ \\
\hline $1,228.0$ & 0.5 & 0.2 \\
$1,229.0$ & .9 & 1.0 \\
$1,230.0$ & 1.4 & 2.1 \\
$1,231.0$ & 19.0 & 11.3 \\
$1,232.0$ & 37.3 & 40.6 \\
$1,233.0$ & 42.2 & 80.7 \\
$1,234.0$ & 50.2 & 126.1 \\
$1,235.0$ & 67.7 & 184.4 \\
$1,236.0$ & 91.1 & 263.3 \\
$1,237.0$ & 112.4 & 366.4 \\
$1,238.0$ & 127.7 & 486.6 \\
$1,239.0$ & 139.6 & 621.0 \\
$1,240.0$ & 148.8 & 764.9 \\
$1,241.0$ & 161.2 & 920.9 \\
$1,242.0$ & 169.4 & $1,086.1$ \\
$1,243.0$ & 176.3 & $1,259.2$ \\
$1,244.0$ & 182.0 & $1,438.5$ \\
$1,245.0$ & 186.6 & $1,622.9$ \\
\hline
\end{tabular}

Table 10. Surface area and storage capacity for Yankee Hill sediment basin (surface area 3.5 acres and storage capacity 11.3 acrefeet at conservation pool elevation of 1,245.24 feet).

\begin{tabular}{ccc}
\hline $\begin{array}{c}\text { Elevation, } \\
\text { in feet }\end{array}$ & $\begin{array}{c}\text { Surface area, } \\
\text { in acres }\end{array}$ & $\begin{array}{c}\text { Storage capacity, } \\
\text { in acre-feet }\end{array}$ \\
\hline $1,240.0$ & 0.4 & 0.2 \\
$1,241.0$ & 1.3 & 1.1 \\
$1,242.0$ & 1.9 & 2.7 \\
$1,243.0$ & 2.4 & 4.8 \\
$1,244.0$ & 2.8 & 7.5 \\
$1,245.0$ & 3.2 & 10.5 \\
\hline
\end{tabular}


Publishing support provided by:

Rolla Publishing Service Center

For more information concerning this publication, contact:

Director, USGS Nebraska Water Science Center

5231 S. 19 Street

Lincoln, NE 68512

(402) 328-4100

Or visit the Nebraska Water Science Center Web site at: http://ne.water.usgs.gov 

8 Printed on recycled paper 